\title{
Vascular \\ Traumatic clivus epidural hematoma: case report and review of the literature
}

\author{
Bernardo Ratilal, MD*, Pedro Castanho, MD, Carlos Vara Luiz, MD, João Oliveira Antunes, MD \\ Department of Neurosurgery, Hospital São José, Lisboa, Portugal \\ Received 8 October 2005; accepted 2 November 2005
}

\begin{abstract}
Background: Traumatic clival epidural hematoma is an extremely rare reported entity.

Case Description: We describe the case of a 26-year-old woman involved in a car accident who presented with a Glasgow Coma Scale score of 13, bilateral abducens palsy, bilateral numbness on the mandibular territory of the trigeminal nerve, and left hypoglossal palsy. Radiological examinations revealed a clival epidural hematoma. The patient was managed conservatively, with clinical improvement of her neurological condition. This is the first traumatic clival epidural hematoma reported in an adult. From a review of the literature, we found only 8 cases.

Conclusion: The pathophysiology of these hematomas is still a subject of debate; occipitoatlantoaxial ligamentous instability may play a role in it. In one third of the cases, bilateral cranial nerve palsies were associated. Apparently, they have a benign outcome.

(C) 2006 Elsevier Inc. All rights reserved.
\end{abstract}

\section{Introduction}

Posterior cranial fossa is an unusual site for traumatically induced mass lesions in which the most frequently reported mass is epidural hematoma. It was first described in 1941 by Coleman and Thomson [2] and represents approximately $1.2 \%$ to $12.9 \%$ of all epidural hematomas [3-5]. The clinical progress is usually silent and slow, but deterioration can be sudden and rapidly fatal as a result of obstructive hydrocephalus if not promptly treated.

Clival epidural hematomas are a subgroup of the posterior fossa epidural hematoma that seem to have a distinct pathophysiology, treatment, and outcome. There are only a few cases reported. The case we report on is the first traumatic clival epidural hematoma reported in an adult.

\section{Case report}

A 26-year-old woman was involved in a high-speed car accident with cervical hyperextension and head trauma. Her

\footnotetext{
* Corresponding author. Tel.: +351 963047176; fax: +351 218841052.

E-mail address: bratilal@yahoo.com (B. Ratilal).
}
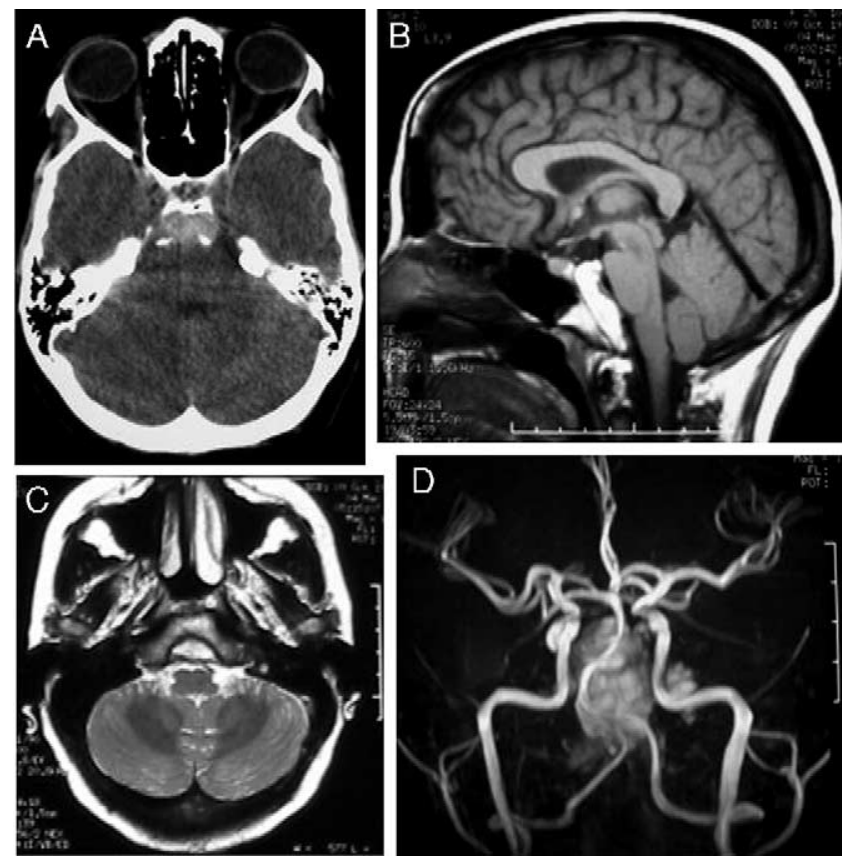

Fig. 1. Neuroimaging workout of our patient showing the clival epidural hematoma. A: Computed tomography scan at admission. B: Sagittal T1weighted unenhanced image. C: Axial T2-weighted unenhanced image. D: Magnetic resonance angiography unenhanced image. 
Glasgow Coma Scale score at admission was 13. She complained of headache and diplopia. Her physical examination revealed right frontal epicranial contusion, bilateral abducens palsy, bilateral numbness on the mandibular territory of the trigeminal nerve, and left hypoglossal palsy.

Plain films of the cervical spine showed a right transverse process aligned fracture of the sixth cervical vertebra, and flexion/extension imaging did not show evidence of occipitoatlantoaxial instability. Computed tomography scan revealed a retroclival hyperdense mass lesion with no significant mass effect or evidence of skull fracture. Magnetic resonance imaging showed a T1- and T2-weighed hyperintense epidural clival lesion with mass effect over the pons and medulla. These findings were consistent with an extracellular metahemoglobin collection compatible with a retroclival epidural hematoma. Magnetic resonance angiography showed no vascular abnormality with the basilar artery pushed to the left (Fig. 1). Ligamentous injury was not visualized on any of the magnetic resonance sequences. Computed tomography scan of the cervical spine confirmed the transverse process fracture. Blood tests including coagulation had no abnormal finding. The patient was managed conservatively, with clinical improvement. On the third day, she was fully conscious with no headache. Two-week control computed tomography scan provided no evidence of residual hematoma. At 4 weeks' follow-up, she had improved her neurological status with only mild diplopia on extreme lateral eye movements and left tongue deviation.

\section{Discussion}

Trauma is the most common cause of extradural hematoma. Most cases are associated with cranial fractures. Unlike supratentorial epidural hematomas, which are caused mainly by arterial lesions, most of those in the posterior fossa are a consequence of venous sinuses injury. Magnetic resonance is the image technique of choice in the diagnosis of these lesions because it allows a more detailed definition of the anatomical relationship between the hematoma and the surrounding structures $[8,12]$.

Traumatic clivus epidural hematomas are exceptional. From a review of the literature, we found only 8 cases (Table 1) [1,6-10,12,13]. Remarkably, all cases, including

Table 1

Summary of patients with traumatic clivus epidural hematoma

\begin{tabular}{|c|c|c|c|c|c|c|}
\hline Series & $\begin{array}{l}\text { Age }(y) / \\
\operatorname{sex}\end{array}$ & $\begin{array}{l}\text { Mechanism } \\
\text { of injury }\end{array}$ & Clinical findings & Other image findings & Treatment & Outcome \\
\hline $\begin{array}{l}\text { Orrison } \\
\text { et al [10] }\end{array}$ & $8 / \mathrm{M}$ & MVA & $\begin{array}{l}\text { GCS }=3 \text {; parietal } \\
\text { epidural hematoma; } \\
\text { anisocoria; massive } \\
\text { hepatic injury; } \\
\text { leg fractures }\end{array}$ & $\begin{array}{l}\text { Dislocation of left } \\
\text { atlanto-occipital joint } \\
\text { with ligamentous } \\
\text { instability; ventricular } \\
\text { hemorrhage }\end{array}$ & $\begin{array}{l}\text { Burr hole to evacuate } \\
\text { the parietal epidural } \\
\text { hematoma }\end{array}$ & Early death \\
\hline $\begin{array}{l}\text { Kurosu } \\
\text { et al [6] }\end{array}$ & $11 / \mathrm{F}$ & $\begin{array}{l}\text { MVA; cervical } \\
\text { hyperextension }\end{array}$ & $\begin{array}{l}\text { GCS }=7 ; \text { central cord } \\
\text { syndrome; leg fracture; } \\
\text { hematuria }\end{array}$ & $\begin{array}{l}\text { Atlantoaxial dislocation; } \\
\text { widening of } \\
\text { sphenooccipital } \\
\text { synchondrosis; } \\
\text { brain stem contusion }\end{array}$ & Conservative & $\begin{array}{l}\text { Good recovery } \\
\text { at } 8 \text { weeks }\end{array}$ \\
\hline $\begin{array}{l}\text { Castillo } \\
\text { et al [1] }\end{array}$ & $11 / \mathrm{M}$ & MVA & $\begin{array}{l}\text { Comatose; severe } \\
\text { headache; dysphagia }\end{array}$ & Normal CT scan & Conservative & $\begin{array}{l}\text { Full recovery at } \\
24 \text { weeks }\end{array}$ \\
\hline $\begin{array}{l}\text { Marks } \\
\text { et al [7] }\end{array}$ & $8 / \mathrm{M}$ & $\begin{array}{l}\text { MVA; cervical } \\
\text { hyperextension }\end{array}$ & $\begin{array}{l}\mathrm{GCS}=6 ; \text { tetraplegia; } \\
\text { respiratory arrest }\end{array}$ & Atlantoaxial dislocation & Conservative & Good recovery \\
\hline $\begin{array}{l}\text { Mizushima } \\
\text { et al }[8]\end{array}$ & $8 / \mathrm{M}$ & MVA & $\begin{array}{l}\text { GCS }=6 \text {; paresis of } \\
\text { upper extremities; } \\
\text { bilateral abducens palsy }\end{array}$ & Atlantoaxial dislocation & Conservative & $\begin{array}{l}\text { Full recovery at } \\
24 \text { weeks }\end{array}$ \\
\hline $\begin{array}{l}\text { Muller } \\
\text { et al [9] }\end{array}$ & $7 / \mathrm{M}$ & $\begin{array}{l}\text { MVA; cervical } \\
\text { hyperflexion }\end{array}$ & $\mathrm{GCS}=6$ & Not present & Conservative & $\begin{array}{l}\text { Posttraumatic } \\
\text { hydrocephalus; } \\
\text { good recovery }\end{array}$ \\
\hline $\begin{array}{l}\text { Suliman } \\
\text { et al [12] }\end{array}$ & $16 / \mathrm{M}$ & $\begin{array}{l}\text { MVA; cervical } \\
\text { hyperextension }\end{array}$ & $\begin{array}{l}\text { GCS }=8 ; \text { left } \\
\text { glossopharyngeal and } \\
\text { bilateral hypoglossal } \\
\text { palsies and right } \\
\text { hemiparesis }\end{array}$ & $\begin{array}{l}\text { Avulsion fracture of the } \\
\text { left occipital condyle; } \\
\text { probable atlantoaxial } \\
\text { ligamentous instability; SAH }\end{array}$ & Conservative & $\begin{array}{l}\text { Full recovery } \\
\text { at } 11 \text { weeks }\end{array}$ \\
\hline Yang [13] & $5 / \mathrm{M}$ & MVA & $\begin{array}{l}\mathrm{GCS}=7 \\
\text { irregular breathing }\end{array}$ & $\begin{array}{l}\text { Craniocervical junction } \\
\text { ligamentous instability }\end{array}$ & Conservative & $\begin{array}{l}\text { Full recovery at } \\
4 \text { weeks }\end{array}$ \\
\hline $\begin{array}{l}\text { Present } \\
\text { report }\end{array}$ & $26 / F$ & $\begin{array}{l}\text { MVA; cervical } \\
\text { hyperextension }\end{array}$ & $\begin{array}{l}\text { GCS }=13 ; \\
\text { bilateral abducens and } \\
\text { left hypoglossal palsies; } \\
\text { bilateral numbness on } \\
\text { the mandibular territory } \\
\text { of the trigeminal nerve }\end{array}$ & $\begin{array}{l}\text { Right transverse process } \\
\text { fracture of the sixth } \\
\text { cervical vertebra }\end{array}$ & Conservative & $\begin{array}{l}\text { Good recovery } \\
\text { at } 4 \text { weeks }\end{array}$ \\
\hline
\end{tabular}

M indicates male; MVA, motor vehicle accident; GCS, Glasgow Coma Scale score; F, female; CT, computed tomography; SAH, subarachnoid hemorrhage. 
ours, were a consequence of motor vehicle high-energy accidents. The mechanism, not yet completely understood, appears to be based on the sagittal dislocation of the dens axis with a detachment of the tectorial membrane from the clivus, resulting in venous bleeding and subsequent epidural hematoma [8]. Children are more susceptible to this phenomenon because the dura is more easily displaced from the skull, leading to venous hemorrhage [11]. Accordingly, all the previously reported cases involved patients younger than 16 years; $75 \%$ had signs suggestive of occipitoatlantoaxial instability in possible relation with cervical hyperflexion/hyperextension. In our patient, we did not find evidence of cervical instability although there was a transverse process fracture as a result of an extreme cervical movement.

Surprisingly, unlike traumatic convexity posterior fossa hematomas [14], a positive correlation between Glasgow Coma Scale at admission and outcome could not be established. Of the 8 patients who suffered severe head injury, only 1 had a negative outcome. This leads us to presume that this type of hematoma has a more benign course consistent with a conservative management.

\section{Conclusions}

Traumatic clivus epidural hematoma is not exclusive of pediatric age and should be considered whenever bilateral cranial nerve palsy is present in a context of head trauma. Although there are few reported cases, it is possible that this entity is often misdiagnosed.

\section{Acknowledgments}

We thank Sergio Lameiras for his assistance.

\section{References}

[1] Castillo C, Lambre H, Meli F. Hematoma agudo extra-axial posttraumatico de clivus. Medicina (B Aires) 1994;54:150-2.

[2] Coleman CC, Thomson GL. Extradural hemorrhage in the posterior fossa. Surgery 1941;10:985-90.

[3] Cordobes F, Lobato RD, Rivas JJ. Observations on 82 patients with extradural hematoma. Comparison of results before and after the advent of computerized tomography. J Neurosurg 1981;54: $179-86$.

[4] Garza-Mercado R. Extradural hematoma of the posterior cranial fossa. Report of seven cases with survival. J Neurosurg 1983;59:664-72.

[5] Hooper R. Observations on extradural haemorrhage. Br J Surg 1959;47:71-87.

[6] Kurosu A, Amano K, Kubo O. Clivus epidural hematoma. Case report. J Neurosurg 1990;72:660-2.

[7] Marks SM, Paramaswaren RN, Johnston RA. Transoral evacuation of a clivus extradural haematoma with good recovery. Br J Neurosurg 1997;1:245-7.
[8] Mizushima H, Kobayashi N, Sawabe Y. Epidural hematoma of the clivus. Case report. J Neurosurg 1998;88:590-3.

[9] Muller JU, Piek J, Kallwellis G. Prapontine epidurale blutung. Zentralbl Neurochir 1998;59:185-8.

[10] Orrison WW, Rogde S, Kinard RE. Clivus epidural hematoma: a case report. Neurosurgery 1986;18:194-6.

[11] Robertson JH, Clark WC, Acker JD. Bilateral occipital epidural hematomas. Surg Neurol 1982;17:468-72.

[12] Suliman HM, Merx HL, Wesseling P. Retroclival extradural hemato$\mathrm{ma}$ is a magnetic resonance imaging diagnosis. J Neurotrauma 2001;8:1289-93.

[13] Yang BP. Traumatic retroclival epidural hematoma in a child. Pediatr Neurosurg 2003;39:339-40.

[14] Zuccarello M, Pardatscher K, Andrioli GC. Epidural hematomas of the posterior cranial fossa. Neurosurgery 1981;8:434-7.

\section{Commentary}

The authors are to be congratulated for their careful evaluation, treatment, and literature review of the rare condition of posttraumatic clival epidural hematoma.

The hypothesis on the condition's relationship to atlantoaxial flexion/extension is reasonable. Conservative treatment, in the absence of progressive neurological deterioration, seems to be the treatment of choice and was certainly successful in this case.

It is interesting to speculate that the survivors of this injury complex, who routinely go on to improve, may be only a small subset of those sustaining the precipitating severe injury mechanism, most of whom may die prior to medical triage. Vigilant observation in the early recovery phase would then still be critical.

\section{David Hunt, MD Maimonides Medical Center Brooklyn, NY 11219, USA}

The authors describe a rare case of clivus epidural hematoma in a young adult. Their review of the literature and case results would indicate that conservative management should be the first line of treatment for the said condition. Only when there is critical compression of posterior fossa content should evacuation be considered, and it must be expected that formidable venous bleeding is to be encountered under this circumstance. The authors have also made a very important point that ligamentous instability in the craniocervical junction must be suspected and actively excluded in such a case.

John D. Laidlaw, MD

Private Medical Center, Royal Melbourne Hospital Parkville, VIC 3050, Australia 